\title{
A 'Greek' Acrostic in Valerius Flaccus (3.430-4)
}

In the first part of Argonautica Book 3 Valerius narrates the famous episode of the involuntary massacre of the Doliones. ${ }^{1)}$ After having been hosted by king Cyzicus, the Argonauts leave his land, but during the same night, because of divine will, they mistakenly sail back to the same place, and unknowingly they face and kill the Doliones in battle. The next morning, when they recognize the bodies of their friends, they mourn and perform funeral rituals. According to Valerius Flaccus, the consequence of the crime is not a storm, as in Apollonius, ${ }^{2}$ ) but an immobilizing sense of guilt that blocks the Argonauts in Cyzicus. Mopsus then performs rituals to purify the Argonauts and to appease the shades of the slain. At the beginning of the purification ritual, when Mopsus approaches Argo's crew, the text presents an acrostic that, to my knowledge, has gone unnoticed.

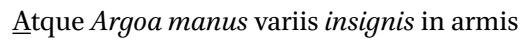
inbat agens lectas aurata fronte bidentes.

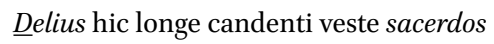
occurrit ramoque vocat, iamque ipse recenti stat tumulo placida transmittens agmina lauro. (3.430-4)

The Argo's crew, striking in sundry gear, marched on, leading choice sheep with foreheads gilded. Then the Delian priest in robes far shining comes up to meet them and with a branch he summons: he stands on tomb's fresh mound and bids them pass with a branch of laurel to propitiate. (tr. Barich 2009)

1) On the whole episode see Manuwald 1999; for the ritual of purification see Boyancé 1935 .

2) A.R. 1.1078 f. In Apollonius' version, the Argonauts cannot leave Cyzicus' land because of a storm provoked by the rage of the dead and their protective deity, the Mother of the gods (Rhea, associated with Cybele). 
The acrostic reads aidos ( $\alpha i \delta \omega \varsigma)^{3}$ ) and, as far as I know, this would be the only example of a Greek word used in acrostic within a Latin poem. $\left.{ }^{4}\right)$

Scholars have been arguing for decades over acrostics (and they still do) and the question of intentionality is always a crucial one. As far as Valerius Flaccus is concerned, I have discussed elsewere his use of this technique in the Argonautica, showing several examples of intentional acrostics.5) Sometimes a text can offer a sequence of letters that coincidentally form a word, ${ }^{6}$ but if this word fits the context of the passage, and it is supported by other structural elements, we might assume that the poet is composing an intentional acrostic. While chance can always be argued, in our particular case I think that the intentionality of the poet can be supported by several considerations.

Ai $\delta$ '́s is notoriously one of the most difficult of Greek words to translate, due to its wide range of use. ${ }^{7)}$ Valerius seems to play on several of its meanings, such as 'shame', 'self-respect', 'regard for others' (for friends), 'compassion', and 'sense of honour', since they all fit the context of the purification ritual well. Scholars have already pointed out the importance of Mopsus' role in the whole passage, as well

3) The anonymous referee (whom I thank, as well as Mnemosyne) points out that "its transcription into the Latin alphabet would be expected to be AEDOS (cf. e.g. AETION for Greek AITION)". It is true that this would be the most expected form, but Lucilius too, for instance, uses AIGILIPS for the Greek $\alpha i \gamma(\lambda ı \psi$ (Lucil. 3.113 aigilipes montes, Aetnae omnes, asperi Athones), when elsewere we find, for instance, aegocephalus (Plin. Nat. 11.204) for $\alpha i \gamma o x \varepsilon \dot{\varepsilon} \varphi \alpha \lambda \circ \varsigma$ or

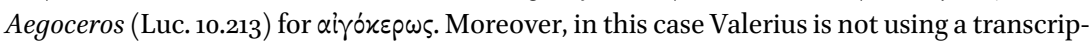
tion of a Greek word in a verse, but as an acrostic, and I think that he deliberately uses the term as a Greek word in order to summon up the full extent of its original power, particularly if the word is intended as a ritual one (see my argumentation below). Valerius' extensive use of Greek words (like that of other post-Augustan poets) is well attested, and his educated aristocratic readers were effectively bilingual; see e.g. Zissos 2008, lvi-lvii.

4) Wordplay and puns on Greek words are quite common amongst Latin poets (see Ahl 1985; O'Hara 1996; Bagordo 2002; Katz 2008 and 2009) and we can find examples also in Valerius Flaccus (see e.g. Spaltenstein 2002, 202), but I have not found any evidence of acrostic Greek words.

5) See Castelletti 2008 (with discussion and bibliography on this technique in Latin literature). The most striking case is laniabor in 4.177-84. See also O Iphi 7.400-4; odia 7.255-8; natus 8.154-8; pace 8.391-4.

6) Emblematic is the case of Hilberg 1899, who compiled a 35-page list of Zufallsakrosticha in all of Latin poetry (from Ennius to Corippus), claiming that only a dozen were intentional. Several scholars over the past few decades proved that he was wrong in a number of cases (see Castelletti 2008, 219-20).

7) On the use of $\alpha i \delta \omega$ s in Ancient Greek literature, see Cairns 1993. 
as the connections between this figure of vates-sacerdos, and the poet himself. ${ }^{8)}$ The position of the words Delius and sacerdos, at the beginning and at the end of the central line of the acrostic, ${ }^{9)}$ emphasizes the link between the figure of the priest and the acrostic. The acrostic can be perceived as a commentary on the scene, made by the poet in margine, or as a ritual word expressed in such a way by the priest himself: the Argonauts are ashamed at what they have done, even if it was unintentional, and they show compassion and regard for their friends. At the same time, the ritual has a precise function, which corresponds to a specific meaning of $\alpha i \delta \omega \varsigma$. In fact, this acrostic seems to be inspired by a Homeric line: ${ }^{.10} \alpha i \delta \omega$ s,

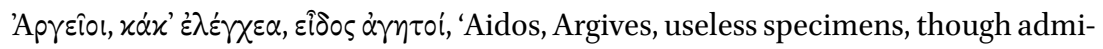
rable in appearance $\left.{ }^{\prime 11}\right)($ Hom. Il. $5.787=8.228)$. As we can see, Valerius puts $\alpha i \delta \omega \varsigma$ in acrostic, and conflates, in the first line, Apreio in Argoa manus (same metrical

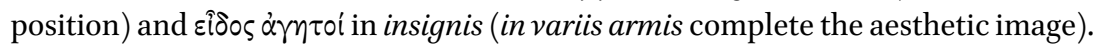
This Homeric line, twice repeated in the Iliad, shows a major function of ai $\delta \omega \varsigma$ : spurring the combatants on. ${ }^{12}$ "Used as an appeal, a reminder of the disgrace of defeat or cowardice, aidos appeals to each individual's concern for his own honour, but it also works to promote the safety of the entire force and to achieve the objectives of the army as a whole". ${ }^{13)}$

In Valerius Flaccus, after the massacre of Cyzicus the Argonauts are unable to react, and they have lost their amor laborum, which is peculiar to the heroic behavior. ${ }^{14)}$ Jason questions Mopsus about the reason of their ignavia, ${ }^{15)}$ and the prophet answers that those who committed blood crimes against their will are tortured by their own minds, and their own deeds gnaw at them. Therefore, 'Indolent, now bold to do no more, their strength is sapped by tears and groveling fear and sickly

8) For Mopsus' role in this passage, see Boyancé 1935 and 1965. For the importance of Mopsus in the poem, see Feeney 1991, 316; Caviglia 1999, 7-8 (Mopsus and other vates as selfrepresentations of Valerius as poet-vates); Zissos 2008 on vv. 205-39.

9) It is often in the central line that the poet places the words most relevant for the comprehension of the acrostic; see Damschen 2004, 108; Castelletti 2008, 226.

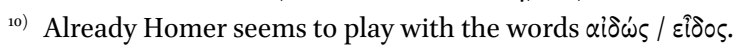

11) Tr. Cairns 1993, 68, who comments: "The warriors are criticized as elenchea, a disgrace; disapproval has been uttered and more is implied, with aidos being the response required to dispel the unfavorable impression". Lattimore translates 'shame, you Argives, poor nonentities splendid to look on'.

12) Cairns 1993, 68.

13) Ibid.

14) V.Fl. 3·367-8 patria ex oculis acerque laborum / pulsus amor segnique iuvat frigescere luctu.

15) V.Fl. 3·375-6 cur immemores famaeque larisque / angimur, aut pariet quemnam haec ignavia finem? 
torpor' ${ }^{\prime 6)}$ But Mopsus states that his careful efforts will resolve the problem, and that is indeed what happens. After the ritual of purification, Mopsus commands the Argonauts to leave and forget what has transpired, because it was required by fate (quae debita fatis, 3.461), and eventually they continue the journey, having regained their spirit (sic animi rediere viris, 3.468).

The acrostic aidos, right at the very beginning of the purification, when Mopsus moves towards the Argonauts, sounds then like an exclamation and an incitation to react, which the sacerdos/poet addresses to the warriors (since they need to recover their status of heroes, and their Homeric $\alpha i \delta \omega \varsigma$ ), just as Hera (disguised as Stentor) and Agamemnon do in the Iliad. Mopsus is a key character, not only in the Cyzicus episode, but within the whole poem, and this acrostic shows at the same time a doctrina sacerdotalis (it is a ritual formula expressed by the Delius sacerdos) and a doctrina poetica. ${ }^{17}$ )

Once again, ${ }^{18)}$ it is tempting to see a connection between the use of acrostics by Valerius Flaccus, and his presumed affiliation to the quindecimvirisacrisfaciundis, ${ }^{19}$ ) especially in this passage, given the importance of the Delius sacerdos. ${ }^{20)}$ It is perhaps wiser to see this as another example confirming that acrostics were commonly used by Latin poets during the first century AD.

University of California Irvine, Department of Classics

Cristiano Castelletti 102 HOB2, Irvine, CA 92697-200o, USA

argocast@gmail.com

Received: May 2010; accepted: May 2010

16) V.Fl. 3.394-6 resides et iam nil amplius ausi / in lacrimas humilesque metus aegramque fatiscunt / segnitiem (tr. Barich 2009).

17) On Valerius as doctus poeta see Zissos 2008, xlii-xlvi; Stover 2010.

18) I already suggested this possibility in Castelletti 2008, 233.

19) For Valerius as quindecimvir see Boyancé 1965 (the description of Mopsus' ritual of purification is one of the key passages for Boyancé's argumentation) and Zissos 2008, xiii-xiv, with bibliography (Newman and Barchiesi have questioned the widespread assumption that Valerius was a quindecimvir). The quindecimviri were also in charge of the cult of Magna Mater/Cybele, and this has been considered a relevant argument, since the Cyzicus episode started because of the anger of this deity (Boyancé 1965, 337-40).

${ }^{20)}$ During the imperial period, the quindecimviri sacris faciundis were priests of Apollo (Plu. Cat.Mi. 4; Liv. 10.8.2) and they were in charge of the Sibylline books, which were composed with acrostics, as witnessed by Cic. Div. 2.112:... atque in Sibyllinis ex primo versu cuiusque sententiae primis litteris illius sententiae carmen omne praetexitur. 


\section{Bibliography}

Ahl, F. 1985. Metaformations. Soundplay and Wordplay in Ovid and Other Classical Poets (Ithaca/London)

Bagordo, A. 2002. Dichtung und Philologie bei Accius am Beispiel seiner Gräzismen und Calquen, in: Faller, S., Manuwald, G. (eds.) Accius und seine Zeit (Würzburg), 39-49

Barich, M. 2009. Valerius Flaccus, Argonautica. A Verse Translation (Gambier, OH)

Boyancé, P. 1935. Un rite de purification dans les Argonautiques de Valérius Flaccus, REL 13, 107-36

1965. La science d'un quindécemvir au premier siècle après J.-C., REL 42, 334-46

Cairns, D.L. 1993. AIDOS. The Psychology and Ethics of Honour and Shame in Ancient Greek Literature (Oxford)

Castelletti, C. 2008. Riflessioni sugli acrostici di Valerio Flacco, GIF 6o, 219-34

Caviglia, F. 1999. Valerio Flacco, Le Argonautiche (Milan)

Damschen, G. 2004. Das lateinische Akrostichon: Neue Funde bei Ovid sowie Vergil, Grattius, Manilius und Silius Italicus, Philologus 148, 88-115

Feeney, D.C. 1991. The Gods in Epic. Poets and Critics of the Classical Tradition (Oxford)

Hilberg, I. 1899. Ist die Ilias Latina von einem Italicus verfasst oder einem Italicus gewidmet?, WS 21, 264-305

Katz, J.T. 2008. Vergil Translates Aratus: Phaenomena 1-2 and Georgics 1.1-2, MD 60, 105-23

2009. Wordplay, in: Jamison, S.W., Melchert, H.C., Vine, B. (eds.) Proceedings of the 2oth Annual UCLA Indo-European Conference (Bremen), 79-114

Manuwald, G. 1999. Die Cyzicus-Episode und ihre Funktion in den Argonautika des Valerius Flaccus (Göttingen)

O'Hara, J.J. 1996. True Names. Vergil and the Alexandrian Tradition of Etymological Wordplay (Ann Arbor)

Spaltenstein, F. 2002. Commentaire des Argonautica de Valérius Flaccus (livres 1 et 2) (Brussels)

Stover, T. 2010. Rebuilding Argo: Valerius Flaccus' Poetic Creed, Mnemosyne 63, 640-50

Zissos, A. 2008. Valerius Flaccus' Argonautica: Book 1 (Oxford) 